\title{
Inclusive Labor Markets as a Solution of Long Term Unemployment in Slovakia
}

\author{
Associate Professor, Anna Harumová \\ University of Economics in Bratislava, Enterprise Finance Department \\ anna.harumova@euba.sk
}

\section{Doi:10.5901/mjss.2016.v7n2p194}

\begin{abstract}
Unemployment of each country influences its performance and is deeply connected to work productivity, inflation and living standard of population. Inflation and unemployment are phenomena, to which modern economy pays higher attention. The proof of their significance is also the fact that they have become the main areas, to which focuses the economical policy. Longterm and the highest rate of unemployment in Slovakia is concentrated in southern districts of Central and Eastern Slovakia. Concentration of high rate of unemployment in some regions causes that traditional tools for solution of this problem are not effective anymore. To new tools for solution of unemployment problem belongs also the concept of inclusive market as a market, of which objective is to provide work opportunities for persons belonging to the category of long-term unemployed. The aim of this paper is to point to long-term unemployment in Slovakia through inclusive labor markets on the basis of theoretical starting points. In the article there is an analysis of unemployment in Slovakia and its comparison with V4 countries. Methodology towards the goal are the analytical and comparative methods.
\end{abstract}

Keywords: unemployment, regions, salaries, inclusive market, the term flexicurity

\section{Introduction}

Unemployment in conditions of Slovakia reaches in some regions the number of over $20 \%$ and our country is on the first place in ranking of long-term unemployment within member countries of European Union. Recent situation in particular regions of Slovakia varies. In some of them are mechanisms working on the market relatively sufficient and the unemployment has rather short-term character. In others, the unemployment rate, also after executed precautions, increases and still greater part of unemployed remains without work more than one year. Tools functioning in regions with lower long-term unemployment rate are becoming ineffective in problematic regions and wrongly set precautions (activation works, graduate practice, grants) only drain out resources, which could be used in more effective way. Therefore, there is an effort to find new tools for solution of this issue. Strategy Europe 2020 was introduced on March 3rd, 2010 by chairman of European Commission, José Manuel Barroso. It has 32 pages and it has defined three main pillars of economical growth, and it is growth intelligent, sustainable and inclusive at the same time. Intelligent and sustainable growth is already for a longer period the part of most of visions and strategies of economies' and regions' development, but the inclusive growth is still overshadowed. The objective of inclusive growth is that the overall economical growth will be generated by all areas of economy and that all areas will also be profitable. However, simplified view on economical indicators of Slovak republic indicates the opposite Bratislava is highly over the national average, West Slovakia culminates around the average rate, but Central and East Slovakia significantly fall behind.

\section{Unemployment Approaches Development in the World}

The term unemployment was for the first time used in the beginning of the $20^{\text {th }}$ century. Great unemployment appeared in 1930 's, during the Great Depression. In this period started to occur various theories, causes, analyzes and approaches to the unemployment.

Stages of survival of unemployment were described already in the 30s of the 20th century by Eisenberg and Lazarsfeld (1938: 72). After the initial shock when a person becomes unemployed, usually the first reaction is refusal to believe this fact. Later, person begins to accept his/her unemployment and stage of optimism is being replaced by the pessimism (Hall - Lindzey, 1997 : 126). It may even go up to complete despair, resignation and fatalism, as Seligman describes it in his theory of "learned helplessness".

Seligman (2013 : 96) concluded that people with repeated stress experience can learn to respond with helplessness. Years later they react in this way evwn in situations that they would be able to handle effectively. 
Dependence of these stages from the time has been expressed by Harrison (Siegrist, 1996 : 14). The last two stages include changes in mental and physical health affected by stress and a load life events such as unemployment for many people. Kleinová (1997 : 363) states that the dissatisfaction of desire to work has serious negative consequences for the future life of the unemployed. Quality of life can be assessed in terms of prevalence of its own survival, awareness, vigor, creativity and communion with others. (Buchtová, 2002 : 171) If people with low qualifications do not expect higher income from possible work than from social benefits, then the situation is dangerously demotivating. According to Brožová (2003 : 105) thus creates the possibility of a culture of life solely on social benefits. Job loss is in most cases an accompanying phenomenon of homelessness as reported by Marek Strnad and Hotovcová (2012: 21).

Unemployed as a social group are among the groups at risk of pathological gambling, as they are often in a state of deprivation. Unemployment, however, is frequently due to gameplay than its cause (Vlčková (2001 : 27). Coping strategies in the specific situation of unemployment were dealed by Frankovský Kentoš and Výrost $(2007: 22)$ in the socalled. Development program for low-skilled unemployed, increasing the likelihood of their application of the labor market.

According to Uramová, theoretical movements significantly differ mainly in the question of what causes the unemployment. „As causes are frequently determined states, unions, enterprises and individuals. Generally, we can speak of two basic marginal approaches: liberalistic, which is based on classical understating of labor market, and on the other side is interventional, which recommends to solve the issue of unemployment by active policy from the state's party." Uramová, 2005: 283).

Liberalistic economy - is characterized by market conception and market balance, which is ensured by so called invisible hand on the market. Each market is in balance, when the supply of work opportunities is equal to demand for jobs. The balance is ensured by market mechanism, which works without and intervention of the state; but on the other hand, the regulation of the state obstructs formation of natural balance. "Workforce is goods as any other, and unemployment is therefore only the result of market mechanism effect, the demonstration of short-term imbalance between demand and supply of work. Decrease of production costs and growth of marginal usefulness of capital leads to increase of investments and also to growing demand for work (Mareš, 1994: 94).

Keynes's approach - Keynes in his work General theory of employment, interests and money (Keynes, 1963: 144) negates the liberal approach to the unemployment. There, he refused the idea of existence of solely voluntary unemployment and introduced the theory of permanent involuntary unemployment. This theory was introduced in the period of Great Depression, when the aggregate demand was in decrease, as well as output and employment rate. As the main reason for long-term unemployment he saw the technological progress; another reason was the demand ineffectiveness. The consequence of technological progress was crowding out and replacement of live work.

Neokeynes's approach to the unemployment tried to unify two significant conceptions - the theory of J. M. Keynes and neoclassical economics. The theory was based on the ability of labor market self-regulation. In the precondition that prices and salaries are perfectly elastic, market balance is formed automatically, and this balance is reached by the full employment. Representatives of neoclassical synthesis acknowledged validity of Keynes's employment model in the short-term period; however in long-term period they think that valid are outcomes of neoclassical approach about elastic salaries and voluntary unemployment.

An English economist $A$. W. Phillips created the curve, by which he demonstrated the substitution relationship between the unemployment and inflation. Phillips, in his work as first put reasons for his thesis, that the lower is the unemployment rate, the higher is the inflation rate (Phillips, 1958: 283 ). He analyzed changes of nominal salary rate in dependence on the level of unemployment. This consideration is based on the precondition that the low rate of unemployment depends on high demand in economy. The asset of Phillips's curve is that it enables to measure the conflict between the full unemployment and price stability. Simultaneously is considered the relation between the change of salary rate of economy as the whole and the change of price level. The original curve was modified several times, until it was stabilized on, so called, modified Phillips's curve suggested by Samuelson and Solow, who have replaced the growth rate of nominal salaries by inflation (Samuelson, $1980: 96$ ).. The initial formulation of Phillips's curve is not used nowadays anymore, but in 1960's was this theory really breaking. Nowadays, this curve is most frequently used in the form, where the pace of salary inflation decreases with the growth of unemployment rate.

Work flexibility brings to the labor market solution of problems connected with the unemployment and bad structure of demand and supply. Work flexibility means adaptation of employment to economical requirements. In the broadest sense, S. Procter and S. Ackroyd define the flexibility as a certain quality, by means of which the entity adapts to the change in to it directed requirements (Procter, Ackroyd, 2001: 368 ). The aim of quantitative flexibility was to adapt the amount of workforce to needs of production. One of possible ways how to reach this goal is to freely hire and fire. The second way is the temporary supply of workforce, when the company rents employees for the certain period. The last kind of quantitative flexibility is elastic working hours. It is the option to modify the work period by the most various ways 
in dependence on needs of the company. The result is that the work will become unstable and its character may be modified. Changes may appear during the working hours, but also by the change of the type of work contract. Negative sign of this theory is increased risk of loss of employment.

The term flexicurity in regards to the labor market, used as the combination of words flexibility and security, was introduced into practice by Danes. Flexicurity characterizes generally the whole Danish labor market. Its asset is that the security and flexibility are not in contradiction, so the security is not to the exclusion of flexibility and vice versa (Schmid. G., 2009: 12). Danish system of labor market is positioned near the liberal systems with the low protection of employees against the dismissal, but at the same time, there is built the network of social insurance with high compensations of salary. The Danish model combines the dynamics of free market economy with social insurance and social balance of Scandinavian type. Danish model of labor market solves in socially balanced way the macroeconomical issues, together with imbalance on the labor market. Its main features are flexibility and security, which are deeply connected to socialization of workforces. This brings on one side collective social sense in regards to the financing of regulations, but at the same time the liberality, as it brings the option to adapt usage of workforces. The model stands on three pillars:

- relatively high compensation of salaries by unemployment,

- great flexibility on labor market in the form of flexible rules of protection against

- dismissal, for example short period of notice,

- active policy of labor market;

The model ensures that unemployed people actively look for jobs or complete some education. In the Danish model, the state takes care about education financing, and that mainly by people with lowest degree of education and with the lowest possibility of connection to the labor market. Flexicurity is focused on greater security in employment and for ensuring the protection of still more complex occupational procedures within the company, but also by transfer into another company and simplification of employment change. Companies' adaptability can be strengthened by means of flexible work schedule and in this way to achieve higher level of elasticity. For companies is also deciding to support the development of internal functional flexibility, related to types of works, forms of work organization and qualification of employees.

In France was in companies with more than 300 employees introduced the system regarding to "prognostic management of workplaces and qualifications." - Discussion about the company's strategy and future needs from the point of view of workplaces and qualifications of employees has to ensure better in-house management of human resources.

In Spain is the key objective the improvement of professional training system. Since 2007, when was signed the trilateral agreement on professional training, employees have the right to take professional holiday for the purpose of specialized professional training, while companies have the option to receive the financial aid for support of projects for specialized professional trainings.

Employees, who lost their jobs as a consequence of restructuring, may become long-term unemployed. In connection to the trilateral agreement, in 2005, Finland created the model of security in changes to the support of employees requalification dismissed for economical reasons. To those are given free days within the period of notice, which can be used for searching for new job; they will receive higher severance pay for the reason of dismissal and they can also use the special program of public services for professional training and searching for a job. On these programs are reserved funds from European fund for adaptation and globalization, European social fund and European fund for regional development. In Sweden are applied "transitional agreements", with the same objective. They include two million employees and are focused on simplification of working inclusion of employees in the case of restructuring.

\section{Inclusive Market as the Solution for Long-term Unemployment}

Inclusive market represents the concept of parallel separated market of services and employees, of which aim is to provide work opportunities for persons classified under the category of long-term unemployed (Páleník, et. al, 2011 : 32). Contently, this concept connects on one of pillars of strategy Europe 2020 - inclusive growth. Inclusive growth represents the economical growth accompanied by high rate of unemployment, contributing to economical, social and regional solidarity and cohesion. Inclusive growth must be profitable for all, by which is excluded the prosperity of only selected sectors, regions, social class, and so on.

It can be said that inclusive market does not represent centrally organized institution, but the set of hundreds or thousands of inclusive companies, which employ employees of the target group (Páleník, $2008: 22$ ). The sources of financing of these companies are not grants, but competed orders in the process of inclusive public supplying (regarding solely to inclusive services). The state has to guarantee only sufficiently large volume of orders. Effectiveness and low 
price is generated by competitors of particular companies by receiving of orders. Taken in consideration that the part of non-working persons has more difficult access to the labor market, due to lower work productivity, necessary is existence of certain positive discrimination for increase of credit of these persons. The total volume of target group in conditions of Slovak republic is approximately 300000 persons; inclusive market should by realistic estimation ensure the work for fifty thousand people. The work on inclusive market is intermediated by, so called, inclusive enterprises.

Inclusive enterprises are registered institutions, of which obligation is to employ $2 / 3$ of the total number of employees from the target group. Target group persons are applying for jobs in inclusive enterprises, which will offer them a job on standard employment contract for a certain period, but maximally for two years, during which it is assumed that they will acquire required amount of working skills necessary for exercise on opened labor market. In regards to the expected number of inclusive employees, there is necessary the existence of approximately one thousand inclusive enterprises evenly allocated in Slovakia. Inclusive enterprises are competing among each other and try to execute all inclusive services. Inclusive services can be executed only by inclusive enterprises, while public supplying is in competence of public institutions - the positive discrimination is thus not carried out by means of grants, but in the form of guaranty of certain amount of orders, of which number can be annually counted to ten thousands. Inclusive services are financed mainly by transfers between chapters (due to saved social benefits and higher tax profits and levies) and from Euro-funds. The task of inclusive enterprise is also equalizing of imbalance between geographical location of the target group and the place of execution of inclusive service.

Implementation of inclusive employment is suitable solution for the issue of long-term unemployment, which seems to be very effective tool. The main asset of inclusive employment is mainly formation of work habits and acquiring of lost self-confidence of long-term unemployed.

\section{Current Development of Unemployment in Slovakia}

Long-term unemployment is one of factors and also consequences of regional differences in Slovak republic. On one hand, the weak economical development of region is the cause of lack of workplaces, of which consequence is the increase of unemployment rate, and also long-term unemployment. While regions with the strong economical development and growth can generate new workplaces also in the period of crisis, other regions are doubly affected. On the other hand, consequence of unemployment is the lower standard of living, as incomes of unemployed from social benefits are lower, than income from work. In regards to the lower living standard, unemployed do not purchase selected goods and services, and if they do, they do it in lower rate and structure than employed. High rate of unemployment pushes the price of work down, as employers have enough potential employees applying for free work positions. The consequence is lower purchasing power of the region, and by this also non-existing generation of workplaces (for example in restaurants, population services, and so on).

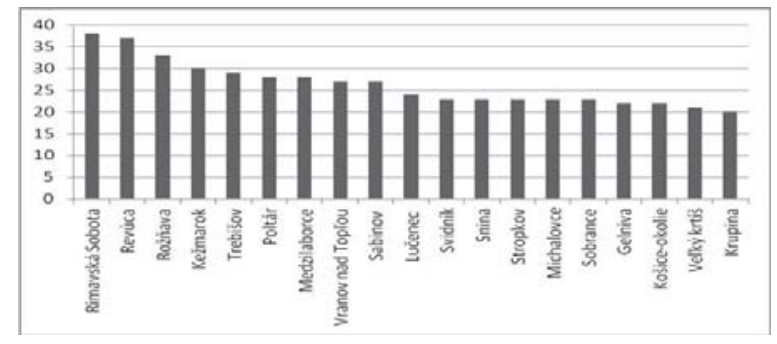

Figure 1. Locations with proportion of long-term unemployed (in percent)

Source: Páleník, M., Oravcová, I. (2013), own processing

Long-term unemployment, in contrast to short-term unemployment, has also other negative features. It is unrealistic to assume that long-term unemployed person will after start of working perform like standard employee, with standard work performance. Also, the change of tax rates or volume of levies will not have appropriate effect comparable with regions, where the labor market works. Consequences of long-term unemployment are negative also outside of economical indicators - they start from grown apathy and satisfaction with the current condition, continue in occasional slight criminality, then follows the transfer on next generations and lowering of their chances in the future, and it all ends in unfriendly moods of majority population. With the growing number of long-term unemployed falling on the total number of 
economically active, still less economically active people have to feed more long-term unemployed. In districts like Rimavská Sobota, Revúca and Rožňava form from the total number of economically active people more than $30 \%$ of long-term unemployed; in districts Kežmarok and Trebišov the situation does not differ much (Figure 1). More than $25 \%$ of long-term unemployed of the number of economically active people live also in Poltár, Medzilaborce, Vranov nad Toplou and Sabinov; and less than $25 \%$, but more than $20 \%$ of long-term unemployed live in another ten cities. On the basis of mentioned facts, it is clear that in areas with below-average results of monitored indicators live inappropriate number of people, who moreover take a large part of this area - so, the current situation is really far from the inclusive situation (Páleník, Oravcová, 2013: 3).

According to "Report on country, Slovakia 2015“ European Commission states that the rate of unemployment slightly decreased in 2014, but it remains over the average of EU $(12,5 \%$ in comparison with $9,9 \%$ in EU-28 in December 2014), while is it mostly structural and it has a long-term character. Weak demand for workplace and low number of free work positions in connection with one of the lowest fluctuation of workplace within EU cause one of the highest rates of long-term unemployment in EU (10\% in comparison with 5,1\% in EU-28 in 2013). Unemployment of young people in December 2014 slightly decreased to $28,9 \%$ (on the lowest rate since 2009), but Slovakia has still one of eight highest rates of young people unemployment in EU. Almost two thirds of unemployed young people search for job a year or longer, which is the largest part from states of EU. The proportion of young people, who are not employed, and are not in the process of education or professional training, is close to average of EU. In February 2014 was adopted updated plan of guarantee execution for young people and implemented were several reforms (e.g. reform of specialized education and training, mentioned below). In 2014 was on salary granted work positions positioned 1694 young people. However, in 2014 only about 10 \% of unemployed young people, who were authorized to receive guarantee for young people, really received one of four offers (work offer, specialized education or training, scholarship). In 2015 should be launched new programs focused on ensuring of employment for long-term unemployed employees with low degree of qualification and other risk groups. Besides this, Slovak offices plan to address inactive young people by means of existing community centers and social workers in practice, but it is not completely clear, how will the concrete support look like. Realization of guarantee system for young people will depend on ensuring of appropriate financing, strengthening of administrative capacities and building of partnerships on local level, to address also broader crowds of unregistered young people, who are not employed or in the process of education or specialized professional training.

Slovakia has launched several reforms focused on elimination of factors discouraging from work in the system of social benefits. Despite significant regional differences in rates of unemployment, the regional mobility of workplace in Slovakia is relatively low and limits assigning of free work positions to suitable applications for work. Minimal wage increased in 2015 by almost 8 \% (to 380 EUR) and net minimal wage (339 EUR) nowadays exceeds the poverty income threshold (337 €).

Approximately $60 \%$ of unemployed in Slovakia are workers with the low qualification and almost $70 \%$ are longterm unemployed (without work longer than one year), while both numbers belong to worst in EU-28. In this regard, European Commission further states that the quality of education and results in the area of education in Slovakia are still very poor. Increase of salaries is still insufficient to attract and maintain talented young people, while mainly initial wages are very low. Slovakia puts in science and research only minimal percent of GDP. The consequence can be further leave of intelligence and loss of competitiveness.

On the picture 2, we can see comparison of salaries of teachers in 2012 in Czech Republic, Hungary, Poland and Slovakia, where clearly lowest wages are in Slovakia.

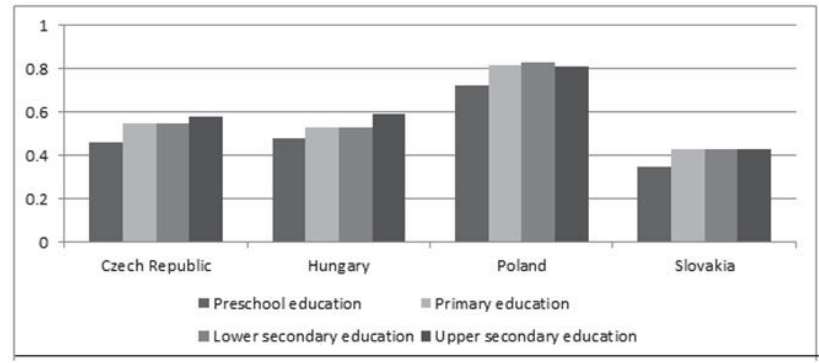

Figure 2. Teachers' salaries in particular countries in 2012 (in thousands of euros)

Source: European Commission, OECD, own processing 
On the picture 3, we can see the comparison of expenses of state administration for education in 2012 (\% GDP) of particular countries, where Slovakia belongs again to countries with lowest expenses.

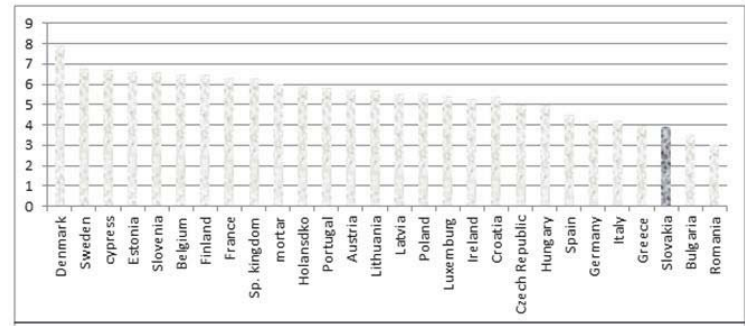

Figure 3. Expenses of state administration for education in 2012 (\% GDP)

Source: European Commission, OECD, own processing

\section{Conclusions and Policy Implications}

The rate of registered unemployment in Slovakia for the end of August 2015 reached 11,32 \%. In comparison with the end of July, it is decrease by 0,14 percent points. The number of available applicants for work reached in the end of previous month 305187 persons. In contrast to the end of July, it is decrease by 3923 people. Year-on-year, the amount of applicants, who could immediately start working, was decreased in August by 33638 persons. The rate of unemployment calculated from the total number of applicants for work, including people unable to work, or people on graduate practice, reached in the previous month $12,86 \%$. Month-on-month it meant decrease by 0,18 percent points; year-on-year it is decrease by 1,25 percent points.

The total number of registered applicants for work in the end of August 2015 represented 346971 persons. In contrast to the end of July, it is decrease by 4850 persons, in comparison with August 2014, it is less by 33697 persons. Also despite the slight decrease of unemployment rate in Slovakia, it is necessary to carry out further precautions and regulations for its decrease.

According to Employment Institute, in order to inclusive market could have sufficient volume for employing of target number of employees, it is necessary to diversify resources of finances and purchasers, and that from villages and towns, through the state budget, up to public institutions and enterprises. They suggest resources as share taxes, Euro-funds, program budgeting, investment projects and social responsibility of enterprises.

Slovak republic government wants to support regions with rate of unemployment higher than 20 percent by new workplaces. It is based on suggestion of act on support of least developed districts, which should relate to areas of Poltár, Rožňava, Kežmarok, Sabinov, Vranov nad Toplou, Revúca and Rimavská Sobota. It wants to refund to companies in this region 45 to 55 percent of investment. Minimal amount of investment into property should be 200000 Euro, with the fact that 100000 Euro has to be covered by equity of the company or entrepreneur. The condition is that there will be created at least ten new work positions. State's money has to be available for levies allowances, refund of commuting costs for employees and also on construction of social accommodation. The help of government is incorporated in its second social package. The act has to be approved in the parliament in the way that it could be in force from December. However, grants for companies and entrepreneurs will probably not be available during next year. The act counts with the fact that government must at first approve the action plan for the given district. This plan will be created for the period of five years and has to include the analysis of the district, evaluation of its development potential, suggestion of regulations and tasks for ensuring the action plan, schedule, methods and resources financing, monitoring and evaluation of achieved progress. Grants, after enforcement of the act, and after meeting all requirements and conditions, have to be provided automatically, without any additional decision-making of politicians or officials. The support will be provided only to district, where "within the period of at least nine quarter-years, during previous twelve consecutive quarter-years was higher than 1,9-multiple of average wage of registered unemployment in Slovakia for the same period."

\section{Acknowledgement}

Indicate in the form of text with reference for example: "This contribution is the result of the project VEGA VEGA (1/1067/15) "Verification, and implementation of modeling business performance in financial decision-making tools". 


\section{References}

Brožová, D. (2003): Social context of the labor market. Prague, SLON, 143 p.

Buchtová, B., et al. (2002): Unemployment - psychological, economic and social problems. Prague: Grada, $236 \mathrm{~s}$.

Eisenberh, P. - Lazarsfeld, P. F. 1938. The Psychological Effects of Unemployment. In: Psychological Bulletin, 35, 1938, s.358-390.

Frankovsk M. - Kentoš, M. - Výrost, J. (2007): Analysis and evaluation of the effectiveness of the program PNKN. TU Institute of Lifelong Learning. Košice, 2007.

Hall, C. S. - Lindsey, G. (1997). Psychology of personality. Bratislava: Media trade - SPN, 1997. 510s.

Klein, R. 1997. Personal survival as a prerequisite for coping with possible unemployment. In: Psychology and patopsychológia child, Vol. 32, 1997, no. 4, p. 360-368.

Marek, J. - Strnad, A. - Hotovcová, L. (2012): Homelessness in the context of social services. Prague: Portal, 175 p.

Mares, A. (1994). Unemployment as a social problem. Cambridge: Polity Press.

Keynes, JM / 1963). General Theory of Employment, Interest and Money. 1st ed. Prague: Publishing House Czechoslovak Academy of Sciences.

Páleník, M. 2008. Flexible forms of employment. In personnel and payroll consultant entrepreneur. Žilina Advisor entrepreneur, 2008. no. 15, p. 149-159.

Páleník, William et al (2011). Inclusive labor markets. Bratislava. Employment Institute.

Páleník, M., Oravcová, I. (2013) The regional aspect of inclusive labor markets. Proceedings of scientific studies. Determinants of Social Development: Social economy as an area of support for European citizenship. Institute of Economic Sciences EF UMB. Matej Bel University.

A. W. Phillips 1958. The Relation between Unemployment and the Rate of Change of Money Wage Rates in the United Kingdom from 1861 to 1957. In Economica. 1958, Vol. 25, no. 100, p. 283-299.

Procter, S; Ackroyd, S. (2001). Analysing advanced manufacturing technology: Labour-centered and technology-centered manufacturing: International Journal of Technology Management, Vol. 11, No. 05/04, 2001, p. 366-380.

Samuelson, P. 1980. Economics. New York: Tata McGraw-Hill Education 1980. 861 p.

Seligman, M. (2013). Learned optimism. BETA Dobrovský. Prague. 2013.

Schmid, G. (2009). Theory of Transitional Labour Markets and 'flexicurity': Lessons for Transition and Developing Countries. Available from: http://www.guentherschmid.eu/pdf/vortraege/turin-09.pdf [accessed. 2015-12-01].

Siegrist, M. (1996) Development of personality as well. 1st ed. Bratislava: Slovak SPN - Young summers, Bratislava.

Uramová, M. (2005). Socio-economic implications of unemployment. Studies oeconomica 24 Banská Bystrica: UMB Faculty of Economics, pp 98.

Vlčková, M. (2001). Gambling - play or disease? Publisher: Educator, no. 6, p. 25-27. 